\title{
Viral Biomarkers in Chronic HBeAg Negative HBV Infection
}

\author{
Emilia Hadziyannis * and Andreas Laras
}

Second Department of Medicine and Laboratory, Hippokrateio Hospital,

National and Kapodistrian University of Athens, Athens 11527, Greece; alaras@med.uoa.gr

* Correspondence: emhadzi@med.uoa.gr; Tel.: +30-213-208-8603

Received: 28 August 2018; Accepted: 21 September 2018; Published: 27 September 2018

\begin{abstract}
Viral biomarkers are important tools for monitoring chronic hepatitis B virus (HBV) hepatitis B early antigen (HBeAg) negative infection, both in its natural course as well as during and after treatment. The biomarkers consist of antibodies against viral epitopes, viral proteins, and molecular surrogate markers of the quantity and transcriptional activity of the stable episomal HBV covalently closed circular DNA (cccDNA) which is located in the nuclei of the infected hepatocytes. HBV deoxyribonucleic acid (DNA) or else viral load measurement in plasma or serum is a marker of HBV replication of major clinical importance. HBV DNA is used for staging and treatment monitoring as described in international scientific guidelines. Quantification of HBV antigens, mainly hepatitis B surface antigen ( $\mathrm{HBsAg}$ ) as well as Hepatitis B core related antigen (HBcrAg), play an important yet secondary role, especially in cases of low or undetectable HBV DNA and has been evaluated for the classification of the inactive carrier state, as a predictor of subsequent HBsAg clearance, treatment outcome, and development of hepatocellular carcinoma (HCC). The measurement of the replicative intermediate HBV RNA in serum is currently evaluated and may also prove to be a significant biomarker particularly in patients treated with nucleot(s)ide analogs. This review focuses on the viral biomarkers mentioned above and their role in HBV, HBeAg negative, infection.
\end{abstract}

Keywords: HBV; biomarker; HBV DNA; HBV RNA; HBsAg; HBcrAg; anti-HBe

\section{Introduction}

Chronic liver inflammation, or chronic hepatitis, is a common disease and a worldwide public health issue. Although, nonalcoholic fatty liver disease (NAFLD) is considered the most rapidly and continuously increasing cause of chronic hepatitis, chronic viral hepatitis is still of major importance, concerning approximately 330 million people worldwide. Specifically, chronic hepatitis B (CHB) affects about 240 million people and although the diagnostic tools are widely available, is still under-diagnosed [1].

The diagnosis and follow up of chronic hepatitis B virus (HBV) infection relies on laboratory viral biomarkers. There are two major categories of HBV biomarkers. The first one is serology, a term comprising the detection and quantification of viral antigens and viral specific antibodies and the second is nucleic acid testing (NAT) for the detection and quantification of HBV genome and its RNA transcripts [2] (Figure 1).

Both serology and NAT are in routine use, not only for the diagnosis of chronic and acute HBV infection, but also for monitoring chronic HBV infection with or without treatment. By definition, HBV serology for hepatitis B early antigen ( $\mathrm{HBeAg}$ ) and the corresponding antibody, is imperative for the specific diagnosis of HBeAg negative CHB. Moreover, serological and molecular biomarkers are used for the identification of the HBeAg negative inactive carrier (IC) state, for treatment initiation and monitoring, and as predictors of HBV and liver related events [3,4]. 


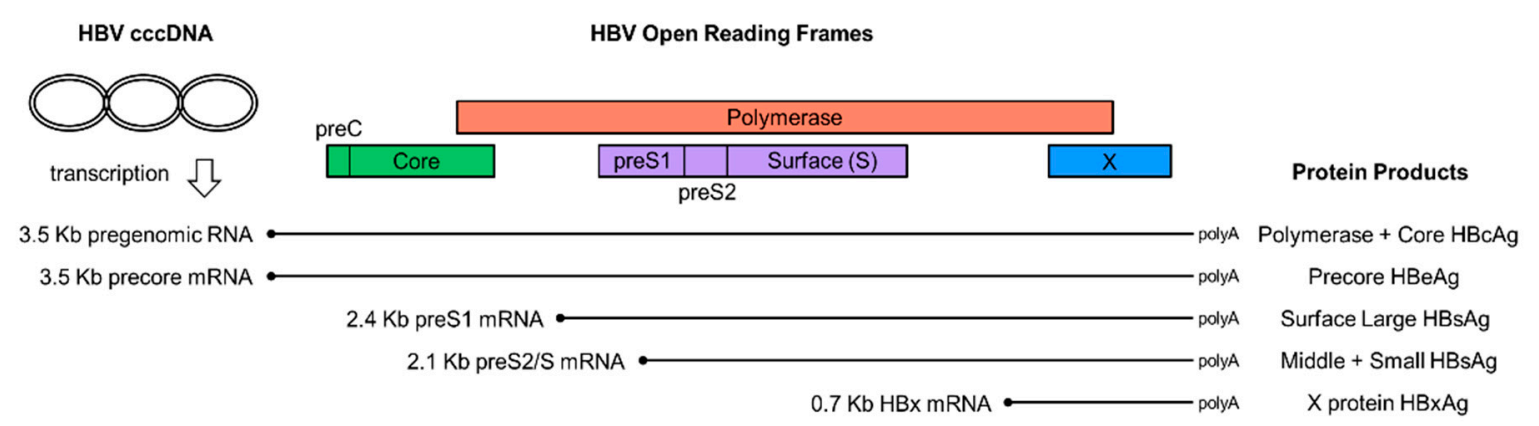

Figure 1. Hepatitis B virus (HBV) gene expression. The HBV covalently closed circular DNA (cccDNA) serves as the template for the transcription of the pregenomic RNA and subgenomic messenger RNA (mRNA) transcripts (shown as thin lines), aligned to a linear depiction of the viral open reading frames (shown as open boxes). The corresponding protein products for each of the major HBV transcript are listed on the right. $\mathrm{HBcAg}$ : HBV core antigen; HBeAg: HBV early antigen; HBsAg: HBV surface antigen; HBxAg: HBV X protein.

\section{Viral Biomarkers}

\subsection{Serology}

\subsubsection{Antigen and Antibody Detection}

The first identified biomarker of HBV infection was the hepatitis B surface antigen (HBsAg), formerly named Australia antigen. Its discovery by Blumberg was the most important milestone that led to the diagnosis, prevention, and treatment of hepatitis B [5]. The detection of HBsAg remains the principal diagnostic tool of HBV infection. HBsAg is produced in excess in HBV infected hepatocytes and circulates in high quantities in the serum [6], consequently, it is a very sensitive as well as specific biomarker for HBV infection. The patient's profile, based on the results of the detection of HBsAg combined with the measurement of the respective anti-HBs antibodies plus the detection of anti-HBc antibodies (total and IgM), is adequate for the diagnosis of acute and for the screening of chronic $\mathrm{HBV}$ infection. Once the diagnosis of chronic HBV infection is made, testing for HBeAg and the corresponding anti-HBe antibody is mandatory and is usually performed by the use of the same methodology, as the previously mentioned serological markers.

Nowadays, extremely sensitive immunoassays on automated analyzers are used for HBV serology based on chemiluminescence (CLIA) and electrochemiluminescence technology (ECLIA) [7,8]. In some cases, however, the increased sensitivity of the HBsAg assays may lead to false positive results. Thus, in patients with HBsAg index values close to the cut off and with inconsistent other serological markers, verification of HBsAg positivity with a confirmatory assay is recommended [9] HBV antibodies and $\mathrm{HBeAg}$ detection are also performed on these automated immunoassay systems [10-12].

In many laboratories, standard enzyme-linked immunoassay (ELISA) is still used for HBV serology as it is an inexpensive alternative that does not require instrumentation other than a microplate reader (photometer). Commercial ELISAs demonstrate high sensitivity $(>99 \%)$ and acceptable specificity $(>95 \%)$ for HBsAg [13], but positive results with low absorbance need to be confirmed. Also, in the case of rheumatoid factor positivity there may be positive or negative interference in these assays [14]. The concordance between ECLIA and ELISA has been found to be $97.05 \%$ for HBsAg, $92.62 \%$ for anti-HBs, $100 \%$ for HBeAg, $76.75 \%$ for anti-HBe, and $58.67 \%$ for anti-HBc. Particularly in patients with $\mathrm{HBeAg}$ and anti-HBe coexistence, the concordance for HBeAg detection was found to be $45.83 \%$ and for anti-HBe $79.17 \%$. The discrepancies of the assays were attributed mainly to differences in their sensitivity [15].

Screening for $\mathrm{HBV}$ is also feasible with rapid tests at the point of care (POC). Point of care serology is available as a single test for HBsAg only or in the form of multiple serological markers detection 
e.g., for hepatitis B, hepatitis C, human immunodeficiency virus (HIV), and syphilis [16]. Rapid tests for HBsAg use capillary blood specimen obtained from a finger stick, are easy to execute and have a sensitivity of greater than $90 \%$ and specificity of over $99.5 \%$. On the other hand, the performance of anti-HBs rapid tests is not optimal, with the major limitation being their low sensitivity [17]. Anti-HBC POC tests are not available.

\subsubsection{Hepatitis B Surface Antigen Quantification}

HBsAg is translated from messenger RNAs (mRNAs) transcribed from covalently closed circular DNA (cccDNA) and/or from HBV sequences integrated in the host genome. The quantification of HBsAg in the past was performed for research purposes by serial serum dilutions that allowed the determination of its titer with qualitative assays [18]. Currently, HBsAg quantification (qHBsAg) in serum is measured in international units per milliliter $(\mathrm{IU} / \mathrm{mL})$ on the same instruments that are used for routine serology, but with different reagents and in most cases with on board dilution of the sample [19-21]. The lower limit of HBsAg detection for the majority of the quantitative assays is $0.05 \mathrm{IU} / \mathrm{mL}$ in undiluted samples, which is higher than the cut off of the respective qualitative assays.

Automated HBsAg quantification has been proven to be highly reproducible and the results between different analyzers show very good correlation [19]. Nevertheless, it is recommended to employ the same assay for monitoring, since differences, especially in the low ranges, might be of importance. The concentration of HBsAg in serum has been studied in every aspect of HBV infection and the test is commercially available and marked for in vitro diagnostics (IVD).

\subsubsection{Hepatitis B Early Antigen Quantification}

HBeAg quantification ( $\mathrm{qHBeAg}$ ) is not yet available as a standardized commercial assay. Nevertheless, it has been evaluated, by in house methodologies, as a possible biomarker in HBeAg positive infection [22]. Monitoring of qHBeAg has been found to be helpful for the prediction of response to treatment and sustained HBeAg seroconversion [23-26]. There are ongoing efforts for the standardization of qHBeAg assays, which is imperative for the generation of robust results and potential clinical use of the test [22,27]. Evidently, in established HBeAg negative hepatitis, qHBeAg is not applicable.

\subsubsection{Hepatitis B Core Related Antigen Quantification}

Hepatitis $B$ core related antigen $(\mathrm{HBcrAg})$ is a rather new marker, that incorporates the quantification $\mathrm{HBcAg}, \mathrm{HBeAg}$, and core related protein p22 (p22cr) in one test. These three proteins are all products of the precore/core HBV gene and share the same 149 amino acid sequence. Obviously, patients positive for $\mathrm{HBeAg}$, which is included in the assay, are found with higher HBcrAg levels than their HBeAg negative counterparts in whom HBcrAg is undetectable in many cases. This test has been used for research only and was first available only in one automated analyzer (Lumipulse, Fujirebio), with lower limit of detection (LOD) being high at $2 \operatorname{logs} \mathrm{U} / \mathrm{mL}$ and lower limit of quantitation (LOQ) at $3 \log \mathrm{U} / \mathrm{mL}[28,29]$. The quantification of the denatured $\mathrm{HBcr}$ proteins is accomplished in reference to a standard curve of known quantities of $\mathrm{HBeAg}$ recombinant peptides $(1 \mathrm{U} / \mathrm{mL}=10 \mathrm{fg} / \mathrm{mL}$ recombinant HBeAg) [30,31].

There is ongoing and expanding research concerning its use as a potential biomarker in both $\mathrm{HBeAg}$ positive and negative phase of the infection, since HBcrAg reflects the transcriptional activity of intrahepatic cccDNA more accurately than $\mathrm{qHBsAg}$, which is produced not only by cccDNA but also from integrated HBV DNA sequences (Figure 2). HBcrAg levels have been associated with intrahepatic cccDNA levels, even in serum HBV DNA negative patients [32].

On the whole, HBcrAg levels display a strong correlation with serum HBV DNA and statistically significant but moderate $(r=0.78)$ correlation with $\mathrm{qHBsAg}$, which is even less pronounced in the HBeAg negative state [30]. 


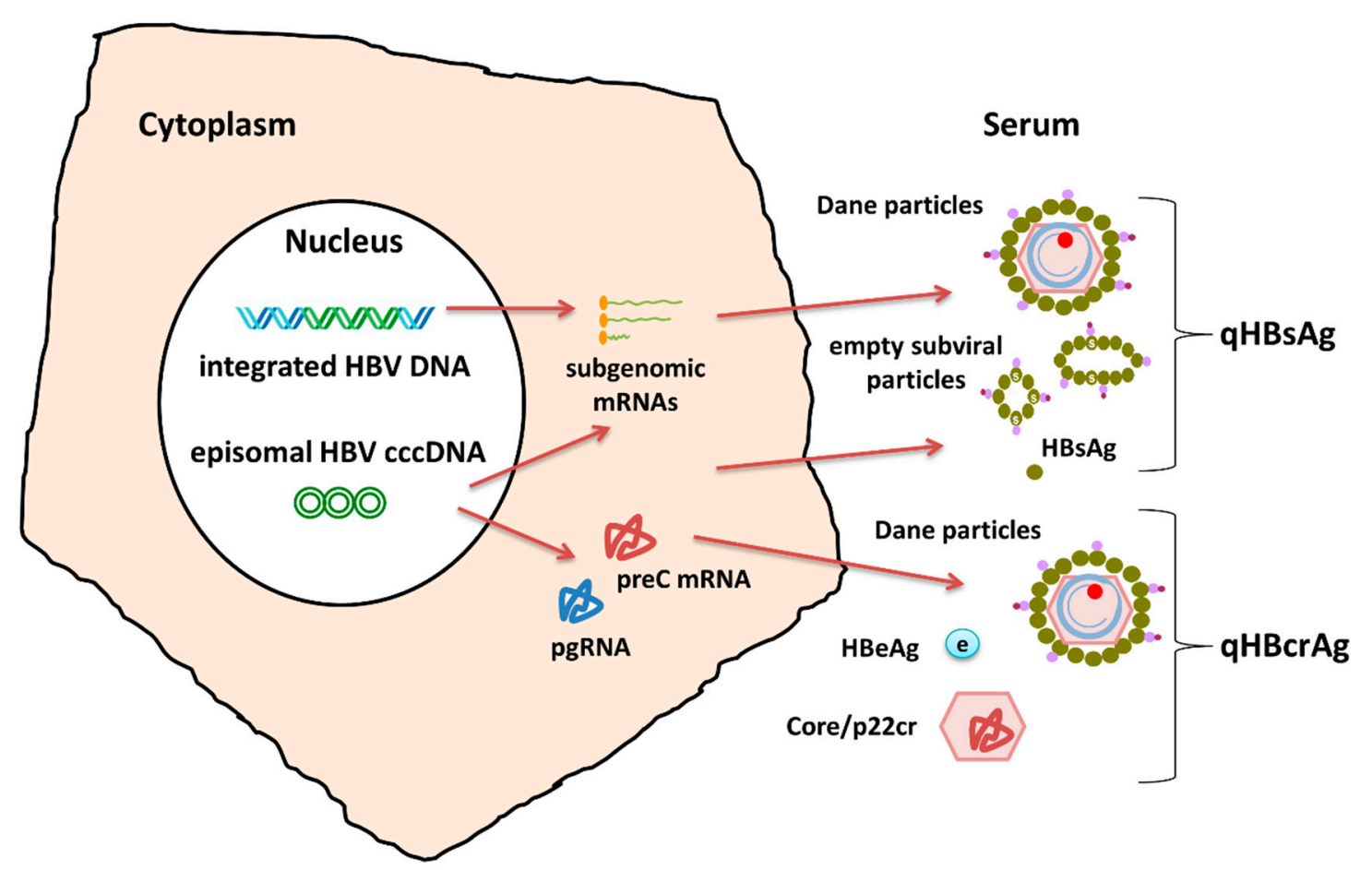

Figure 2. Serum HBsAg reflects the transcriptional activity of both cccDNA and integrated HBV sequences. preC mRNA: precore messenger RNA; pgRNA: pregenomic RNA; qHBcrAg: quantitative HBV core related antigen.

\subsection{Molecular Markers (Nucleic Acid Testing)}

\subsubsection{Hepatitis B Virus Deoxyribonucleic Acid}

Hepatitis B Virus DNA, the genomic nucleic acid of the virus and internal constituent of the core particle, was identified by 1975 and has been sequenced since 1980 but was not used as a biomarker until the molecular techniques advanced to a level permitting their use in specialized clinical laboratories. Actually, until then, the presence of HBeAg was solely associated with active viral replication and active liver disease. With the application of low sensitivity molecular hybridization techniques for serum HBV DNA measurement in HBeAg negative patients, it became clear that although the viral load is higher in HBeAg positive individuals, there is a proportion of HBeAg negative patients who have detectable HBV DNA and active hepatitis [33-35].

Subsequently, with the advent of polymerase chain reaction (PCR) assay for nucleic acid amplification and branched DNA for hybridized signal amplification, HBV DNA measurements became an important viral biomarker. Viral load measurement is currently accomplished with concurrent detection and quantification of HBV DNA in plasma or serum by sensitive real time PCR assays. Several manufacturers provide real time PCR platforms and reagents approved for patient diagnostic use (IVD marked). Some examples of the most commonly used assays are the Roche COBAS TaqMan HBV Test, Abbott RealTime HBV Assay, Siemens VERSANT HBV DNA, and Qiagen artus HBV RG PCR. These and even newer assays demonstrate good reproducibility with low imprecision, as measured by the coefficient of variation (CV $0.5-4 \%$ ) and excellent correlation between the different systems $(r>0.9)[36,37]$. Moreover, point of care NAT instrumentation is expanding their menu options to include HBV DNA testing. The current available HBV DNA POC assays are used for research only. Their performance appears to be similar to the assays used in central laboratories on automated or semi-automated analyzers, thus it is probable that some POC NAT HBV DNA tests and instruments are going to be approved for IVD use in the near future [38]. 
According to the American Association for the Study of Liver Diseases (AASLD) guidelines for treatment of chronic hepatitis B and the European Association for the Study of the Liver (EASL) clinical practice guidelines, the required sensitivity for HBV DNA detection is $10 \mathrm{IU} / \mathrm{mL}[39,40]$. The PCR assays that are commonly used demonstrate aLOD which is usually lower than $10 \mathrm{IU} / \mathrm{mL}$ and a higher limit of quantification (LOQ). Therefore, a not quantifiable but detectable HBV DNA result is probable and both laboratory and clinical personnel need to be aware of this possibility. The genetic variability of different HBV genotypes and subgenotypes appears to have minimal, if any, effect in HBV DNA quantification. Nonetheless, mutations in the primer or probe binding regions may lead to underestimation of the viral load [41].

HBV viremia can be measured not only in fresh blood, but also in dried blood spots (DBS) of whole blood collected by venipuncture or capillary blood collected by finger puncture. The DBS specimens are sent to a central laboratory where they are extracted and tested with conventional HBV DNA techniques. This approach, although not IVD marked as yet, could be important in resource restricted areas with limited access to NAT. In a recent meta-analysis of 12 studies meeting the inclusion criteria, the pooled estimate of sensitivity was $95 \%$ (95\% confidence interval (CI): 83-99) with a higher specificity at 99\% (95\% CI: 53-100) for HBV DNA detection in DBS. The correlation with serum assays was reported in five studies and was found to be strong $(r=0.6-0.96)$ but the LOD was higher for DBS (914-2000 IU/mL). DBS sample storage conditions do not seem to affect the results of HBV DNA detection [42].

The measurement of HBV DNA in oral fluid samples, a different and slightly cheaper approach for the detection of active viral replication, has been used and evaluated in few studies [43-46]. This approach lacks in sensitivity particularly in the HBeAg negative infection and does not appear to be an appropriate alternative.

Additionally, recent advances in technology, made possible the direct detection and quantification of HBV cccDNA in serum, which is released into circulation due to the destruction of infected hepatocytes [47]. There is still need of detailed and extensive studies and of course wider availability of the latest technology, in order to start considering cccDNA in serum as a robust clinical biomarker.

\subsubsection{Hepatitis B Virus Genotype}

HBV is classified in at least 10 genotypes (A to J) based on genetic divergence of more than $8 \%$ and further in subgenotypes within HBV genotypes with divergence of $>4 \%$. HBV genotypes and subgenotypes have distinct geographical distribution. There is increasing evidence of association of genotypes with disease progression and the pathogenesis of HBV infection [48].

The gold standard method for the identification of HBV genotype is whole genome sequencing followed by phylogenetic analysis [49], but most commonly, sequence of the preS-S/pol gene with comparison (sequence alignment) to HBV genotype consensus sequences or the line probe assay, are used [50,51]. It is of interest that mutations in the precore region of $\mathrm{HBV}$, confirmed by sequencing, prevent the production of HBeAg (mainly the G1896A substitution), and are prevalent in HBeAg(-) patients with active liver disease and HBV genotypes D, C, and B [52,53].

The same methods that are applied for genotyping, are also used for the detection of genetic resistance of HBV to NAs [54].

Although different HBV genotypes seem to have diverse biological behavior, HBV genotyping is not used as a routine viral biomarker most probably due to their already recognized geographical distribution.

\subsubsection{Hepatitis B Virus Ribonucleic Acid}

The HBV cccDNA nuclear episome, is the template for transcription by host enzymes producing the viral mRNA transcripts which are translated into viral proteins, as well as the $3.5 \mathrm{~kb}$ pregenomic (pg) RNA which is the template for reverse transcription. Synthesis of the minus (-) strand DNA and synchronous degradation of the RNA pregenome is followed by partial synthesis of variable length 
plus (+) strand leading to the production of mature viral particles containing the relaxed circular (RC) DNA genome. Virions are either enveloped and secreted or recycled to the nucleus to increase the available cccDNA pool. However, HBV RNA can be detected in the serum of either HBV DNA positive or negative patients in the natural course of $\mathrm{CHB}$ and under treatment [55-62]. Several investigators have confirmed that at least the majority of serum HBV RNA is pgRNA encapsidated in virus-like particles [62-64], however other HBV RNA species have been detected both in vivo and in vitro [64-67].

Serum HBV RNA is currently under evaluation as a surrogate non-invasive marker, for monitoring intrahepatic cccDNA transcriptional activity. Detectable HBV RNA in the serum is indirect evidence for cccDNA persistence. A number of different experimental methods for the quantification of intrahepatic and serum HBV RNA are utilized based on quantitative real-time RT PCR assays, however there is no consensus on a single technique and commercial available assay for the detection of HBV RNA. Units used in this experimental setting are either HBV RNA copies/mL or IU $/ \mathrm{mL}$ of serum, independently standardized by investigators.

\section{Clinical Significance of Viral Biomarkers in HBeAg(-) Infection}

\subsection{Biomarkers for the Diagnosis of Chronic HBeAg Negative Hepatitis B Virus Infection}

The diagnosis of chronic hepatitis B virus (HBV) infection is made based on the presence of hepatitis B surface antigen (HBsAg) in serum over six months or a specific serological pattern that includes positive $\mathrm{HBsAg}$, negative respective antibody (anti-HBs) and positive total core antibody (anti-HBc) with negative IgM anti-HBc (Table 1).

Table 1. Hepatitis B Virus (HBV) serology interpretation.

\begin{tabular}{ccccc}
\hline HBsAg & Total Anti-HBc & IgM Anti-HBc & Anti-HBs & Interpretation \\
\hline- & - & - & - & No HBV \\
- & - & - & $+{ }^{1}$ & infection- susceptible \\
- & + & - & + & HBV immune-vaccinated \\
+ & + & + & - & Acute HBV infection \\
+ & + & - & - & Chronic HBV infection \\
- & + & - & - & Inconclusive ${ }^{2}$ \\
\hline
\end{tabular}

${ }^{1}$ anti-HBs $>10 \mathrm{mIU} / \mathrm{mL}^{2}{ }^{2}$ Past Infection (more common), False positive anti-HBc, Occult HBV infection. HBsAg: hepatitis B surface antigen; Anti-HBc: hepatitis B core antibody; anti-HBs: hepatitis B surface antibody.

The differentiation between $\mathrm{HBeAg}$ positive and negative chronic infection is made with the use of two additional serological markers namely the HBeAg and the respective antibody. Depending on how close to $\mathrm{HBeAg}$ seroconversion the patient is, $\mathrm{HBeAg}$ negative patients may be anti-HBe negative or positive. If a patient was known to be HBeAg positive and recently seroconverted, serial determinations are necessary to establish that the patient transcended to the HBeAg negative stage of chronic HBV infection.

Occasionally, a non-diagnostic serological profile with negative HBsAg and anti-HBs but positive anti-HBc is encountered. Although in the majority of these cases this profile is due to past HBV infection there is a possibility of occult chronic HBV infection. Occult HBV infection is defined as HBsAg negative and HBV DNA positive in serum and/or liver [68-73]. In circumstances where patients positive for anti-HBc only, are going to receive immunosuppressive therapy it is imperative to be tested for HBV viremia with NAT (HBV DNA). Immunosuppression may lead to HBV reactivation, thus prophylactic antiviral treatment is implemented [74,75].

\subsection{Biomarkers for the Identification of the Inactive Carrier State}

HBeAg negative patients with chronic HBV infection are categorized in two main states. In the inactive carrier state (recently renamed by EASL as 'HBeAg negative chronic infection'), there is limited 
viral replication and liver inflammation [40]. The inactive HBV carrier presents with normal alanine aminotrasferase (ALT) levels (less than $35 \mathrm{U} / \mathrm{L}$ in males and less than $25 \mathrm{U} / \mathrm{L}$ in females) and low $(<2000 \mathrm{IU} / \mathrm{mL})$ or undetectable HBV DNA. Although the above cut-offs are based on international guidelines, the characterization of a patient as inactive carrier requires serial determinations of ALT and HBV DNA, every $3-4$ months for the first year and subsequently every 6 months. This approach is imperative due to the fluctuations of HBV DNA and ALT that occur in patients at the second state of HBeAg negative infection with active hepatitis $[39,40,76]$.

Since close follow up and serial testing of two biomarkers is essential for the identification of inactive carriers, the addition of a third biomarker has been evaluated. Given that the majority of inactive HBV carriers, have lower HBsAg levels in serum than patients with active inflammation $[77,78]$, the first biomarker that was studied was qHBsAg. In a thorough study on HBV genotype D infection, qHBsAg values at a single time point of less than $1000 \mathrm{IU} / \mathrm{mL}$ in combination with $\mathrm{HBV}$ DNA $<2000 \mathrm{IU} / \mathrm{mL}$ and normal ALT demonstrated a diagnostic accuracy (DA) of $94.5 \%$ for the identification of the inactive carrier state, compared to monthly monitoring with the latter two biomarkers for one year. More specifically, the sensitivity of a single three-markers measurement was $91.1 \%$, a specificity of $95.4 \%$, a positive predictive value (PPV) of $87.9 \%$, and a negative predictive value (NPV) of $96.7 \%$ [79]. Similar results have been observed in other HBV genotypes. In one study of 1068 Taiwanese HBeAg negative patients that had been diagnosed as HBV carriers, infected with HBV genotype B or C, the relationship between HBsAg level $>1000 \mathrm{IU} / \mathrm{mL}$ and the development of $\mathrm{HBeAg-negative} \mathrm{hepatitis} \mathrm{in} 13$ years follow up was found to be significant (hazard ratio $(\mathrm{HR})=1.5$, $95 \% \mathrm{CI}=1.2-1.9)$ and HBsAg $<1000 \mathrm{IU} / \mathrm{mL}$ in combination with low HBV DNA and ALT were found to be useful for identifying minimal-risk HBV carriers [80]. In the REVEAL cohort, in patients infected with B or C genotype, the combined testing with the same HBsAg cut-off, showed diagnostic accuracy for IC of $78 \%$ [81]. This HBsAg threshold of $1000 \mathrm{IU} / \mathrm{mL}$ seems to be the most reliable one for the differential diagnosis of $\mathrm{CHB}$ and the inactive carrier state [82]. The use of a lower qHBsAg cut-off e.g., $100 \mathrm{IU} / \mathrm{mL}$ for increased specificity, results in significant decrease in sensitivity (35\%) [83]. Besides qHBsAg, the addition of liver stiffness measurement (LSM) as a fourth parameter, with a cut off of $6.2 \mathrm{kPa}$ further improves the diagnostic accuracy of testing ALT, HBV DNA, and qHBsAg in a single time point, showing $100 \%$ specificity, $96 \%$ sensitivity, $100 \%$ PPV, $92 \%$ NPV, and $97 \%$ DA for the identification of ICs [84].

Recently, it was suggested that serum HBcrAg is more accurate than $\mathrm{qHBsAg}$ for the identification of inactive carriers, regardless of hepatitis B virus genotype [85]. In this study, the diagnostic accuracy of $\mathrm{HBcrAg} \leq 3 \log \mathrm{U} / \mathrm{mL}$ combined with $\mathrm{HBV} \mathrm{DNA} \leq 2000 \mathrm{IU} / \mathrm{mL}$ was $87 \%$ for genotype $\mathrm{D}$, lower for genotypes $\mathrm{F}$ or $\mathrm{H}(73 \%)$ but higher for genotypes $\mathrm{A}$ and $\mathrm{E}$ ( 91 and $94 \%$ ).

Some patients who display HBeAg negative serological profile with normal ALT, low viremia and/or qHBsAg higher than $1000 \mathrm{IU} / \mathrm{mL}$, have a benign course of the infection and a proportion of them fulfill the criteria of IC in later time. In a recent study with such population included, the combined qHBsAg and HBV-DNA quantification had a diagnostic accuracy of $65.4 \%$ and $100 \%$ NPV for the identification of ICs. In this study HBV-DNA $\leq 2000 \mathrm{IU} / \mathrm{mL}$ and HBcrAg $<3 \log$ or $\mathrm{HBV}$ DNA $\leq 2000 \mathrm{IU} / \mathrm{mL}$ and total anti-HBc $\leq 16,937 \mathrm{IU} / \mathrm{mL}$ had higher and almost the same DA around $86.5 \%$ and their diagnostic performance was improved by combing HBV-DNA $\leq 2000 \mathrm{IU} / \mathrm{mL}$, HBcrAg $\leq 3 \log$ and total anti-HBc $\leq 16,937 \mathrm{IU} / \mathrm{mL}$ (DA $89.5 \%$, sensitivity $93 \%$, specificity $84.8 \%$, PPV 88.9\%, NPV 90.3\%) [86]. Total anti-HBc was quantified by a double-antigen sandwich immune-assay, calibrated using WHO standards.

The biological importance and clinical relevance of serum HBV RNA during the natural course of HBV infection and the differentiation between HBeAg negative carriers and active infection remain unclear. An early study suggested that HBV RNA in serum could be a useful marker for the recognition of the stages of chronic HBV infection [61]. Recently, HBV RNA levels were found to be independently associated with HBeAg status, serum ALT, HBV genotype, and the presence of BCP variants, in a large multiethnic cohort including $122 \mathrm{HBeAg}(-)$ individuals (80\% HBV genotype D) [87]. In another 
study including $24 \mathrm{HBeAg(-)}$ patients (genotype B or C), it was shown that serum HBV RNA levels best correlated with intrahepatic HBV RNA levels, reflecting cccDNA transcriptional activity, rather than with intrahepatic cccDNA itself. The correlation with cccDNA, observed in $\operatorname{HBeAg}(+)$ patients, was not found in the $\mathrm{HBeAg}(-)$ group. No correlations between liver injury or histopathology and HBV-RNA levels were observed, nonetheless, the ratio of HBsAg to serum HBV-RNA was found to be the highest in IC patients [88]. Similarly, in a study of CHB patients, the correlation between serum HBV RNA and intrahepatic cccDNA levels was reported to be dependent on the serostatus of $\mathrm{HBeAg}$ and was not found in HBeAg(-) patients [89]. Furthermore, in an investigation that included $\operatorname{HBeAg}(-)$ negative subjects, the authors proposed the arithmetic addition of serum RNA on serum DNA levels in order to most accurately reflect intrahepatic cccDNA levels. However, this heterologous combination also failed to produce a correlation between serum RNA and liver cccDNA in the group $\operatorname{HBeAg(-)}$ chronically infected individuals [90]. Thus, concerning HBeAg(-) CHB, it is not clear whether or not and in what context serum HBV RNA can serve as a biomarker during the natural course of infection. Although correlation with intrahepatic cccDNA levels is poor, serum HBV RNA reflects viral activity at some level, specifically the transcriptional activity of cccDNA. However, its biological and clinical significance in the progression and pathogenesis of $\mathrm{HBV}$ infection require further investigation.

\subsection{Biomarkers for the Prediction of Spontaneous HBsAg Clearance}

Since $0.4-2.3 \%$ of HBe Ag negative inactive carriers clear HBsAg yearly [91-93], AASLD in 2018 suggested as practice guidance that HBeAg negative ICs should be tested annually for HBsAg [76].

In mostly Asian studies of patients infected with $\mathrm{HBV}$ genotypes B and $\mathrm{C}$, it has been shown that the levels and kinetics of HBsAg in serum are predictors of subsequent spontaneous HBsAg loss. In one of the first studies, a threshold of baseline qHBsAg $\leq 100 \mathrm{IU} / \mathrm{mL}$ had $75 \%$ sensitivity and $91 \%$ specificity to predict subsequent HBsAg seroclearance, which was not associated with baseline serum HBV DNA [94]. Very low qHBsAg < $10 \mathrm{IU} / \mathrm{mL}$ was found to be an excellent predictor of its clearance, with a hazard ratio (HR) 13.2 compared to levels above $1000 \mathrm{IU} / \mathrm{mL}$ [80]. In another study, a baseline qHBsAg $<200 \mathrm{IU} / \mathrm{mL}$ resulted in a sensitivity of $84.2 \%$ and specificity $73.4 \%$ and qHBsAg kinetics, that is an annual $0.5 \mathrm{log}$ reduction, in a sensitivity of $62.8 \%$ and $88.7 \%$ specificity for the prediction of HBsAg clearance, in a three year follow-up period [95]. More recently, in a cohort of patients with 3.08\% annual HBsAg clearance rate, baseline qHBsAg levels predicted HBsAg loss (AUROC 0.965 (95\% CI, 0.947-0.980)), with baseline levels < $10 \mathrm{IU} / \mathrm{mL}$ showing diagnostic an accuracy of $93.4 \%$, a sensitivity of $87.2 \%$, a specificity of $94.8 \%$, a positive predictive value of $79.1 \%$, and a negative predictive value of $97.0 \%$ [96]. In addition, a scoring system for the prediction of HBsAg seroclearance in $\mathrm{HBeAg}$-seronegative chronic hepatitis B patients with genotype B or C infection has been proposed incorporating baseline qHBsAg and HBV DNA levels [97].

In a recent study, in patients infected mainly with $\mathrm{HBV}$ genotype $\mathrm{D}$ and $4.6 \%$ annual serum HBsAg clearance, the combination of qHBsAg $\leq 100-\mathrm{IU} / \mathrm{mL}$ with HBV-DNA $\leq 200-\mathrm{IU} / \mathrm{mL}$ exhibited good performance $(87.5 \%$ DA, $84.2 \%$ sensitivity, $88.2 \%$ specificity, $66.7 \%$ PPV, and 95.2\% NPV) for the prediction of HBsAg loss. Baseline q HBsAg levels were independently correlated with HBsAg clearance and were significantly lower (median 0.75 vs. $2.81 \log 10 \mathrm{IU} / \mathrm{mL}, p<0.001$ ) in patients who cleared HBsAg. Yearly decline of qHBsAg was also found to be a predictive factor being higher in patients who cleared HBsAg (median 0.22 vs. $0.020 \log 10 \mathrm{IU} / \mathrm{mL} /$ year, $p<0.001$ ). HBcrAg was not found to be a predictor of HBsAg loss [86].

\subsection{Treatment Monitoring}

The clinical target of treatment in HBeAg negative hepatitis is to stop the progress of liver disease to cirrhosis and/or HCC. According to current guidance, therapy in HBeAg negative hepatitis is recommended in patients with elevated ALT $\geq 2 \times$ upper limit of normal (ULN) and HBV $\mathrm{DNA} \geq 2000 \mathrm{IU} / \mathrm{mL}$ and in cirrhosis irrespective of ALT [76]. These patients are in an immune active state with liver inflammation, viral replication, and transcriptional activity or they already 
have severe liver damage. The preferred regimen is an antiviral nucleos(t)ide analog (NA) with high genetic barrier (entecavir-ETV, tenofovir-TDF, and tenofovir alafenamide-TAF). Pegylated interferon (Peg IFN), which is not safe in cirrhotics and contraindicated in patients with decompensated cirrhosis, is used sometimes in patients with mild to moderate disease. Older NAs, in which the development of resistance is a major issue, are still used in some cases or in some countries due to their lower price.

The measurable goals of treatment are biochemical response with normalization of ALT levels in serum with viral remission with undetectable HBV DNA (complete viral response) in blood and ultimately functional cure which corresponds to HBsAg clearance. HBV DNA is the crucial biomarker used for monitoring the virologic response in treatment with NAs (Table 2).

Table 2. HBV virological on treatment monitoring and evaluation of results.

\begin{tabular}{|c|c|c|}
\hline & HBV DNA & Comment \\
\hline Primary non-response & Drop $<1 \log 10 \mathrm{IU} / \mathrm{mL}$ & Treatment week 12 \\
\hline Partial virological response & Detectable and drop > $1 \log 10 \mathrm{IU} / \mathrm{mL}$ ) & $\begin{array}{c}\text { Treatment week } 24 \text { (Low GB NA) } \\
\text { or } 48 \text { (High GB NA) }\end{array}$ \\
\hline Complete virological response & Undetectable & Treatment week 48 \\
\hline Viral breakthrough $^{1}$ & $\begin{array}{l}\text { Increase }>1 \log _{10} \mathrm{IU} / \mathrm{mL} \text { compared to nadir } \\
\text { achieved during treatment, or detectable }> \\
100 \mathrm{IU} / \mathrm{mL} \text { when previously undetectable }\end{array}$ & $\begin{array}{c}\text { Confirmed in } 2 \text { measurements } \\
1 \text { month apart }\end{array}$ \\
\hline Functional cure $^{2}$ & Undetectable and HBsAg negative & Anti-HBs +/- \\
\hline \multicolumn{3}{|c|}{$\begin{array}{l}\text { GB: genetic barrier; NA: nucleos(t)ide analog; }{ }^{1} \text { In virological breakthrough, treatment compliance should } \\
\text { be considered. In compliant patients virological breakthrough is related to HBV drug-resistance; }{ }^{2} \mathrm{HBsAg} \\
\text { seroconversion is considered the optimal endpoint of treatment, even if it does not correspond to complete } \\
\text { viral clearance and covalently closed circular DNA (cccDNA), while in low levels, is still found present in } \\
\text { infected hepatocytes. }\end{array}$} \\
\hline
\end{tabular}

HBV cccDNA is responsible for viral persistence during prolonged antiviral therapy $[98,99]$ and the production of pg HBV RNA reflects cccDNA transcriptional and replicative activity. Long term treatment with NAs results in suppression and undetectability of serum HBV DNA levels, by the inhibition of reverse transcription. This process does not directly affect the transcriptional activity of ccCDNA and the production of pgRNA, mRNAs, and viral proteins is continued by the residual intrahepatic cccDNA [100]. Thus, HBV RNA pregenomes may accumulate in the hepatocytes during treatment and be packaged and exported in virion-like particles in the serum. It was firstly shown that, in patients receiving lamivudine therapy, HBV RNA becomes detectable in serum during treatment and that is inhibited by interferon-alpha (IFN- $\alpha$ ) $[59,101]$. It has also been postulated that serum HBV RNA might be a predictor of early emergence of viral resistance mutations during NA therapy $[55,102]$. In one fairly recent study that included $12 \mathrm{HBeAg}(-) \mathrm{NA}$ treated patients, a positive correlation between the levels of serum HBV RNA and HBV DNA as well as with qHBsAg was demonstrated and the HBV RNA kinetics of $\mathrm{HBeAg}(-)$ and $\mathrm{HBeAg}(+)$ patients who achieved seroconversion were found to be similar [65]. More recently, in a study on entecavir treated patients, including $22 \mathrm{HBeAg}(-)$ with genotype B or C HBV infection, it was shown that serum HBV RNA levels reflect intrahepatic viral activity and are associated with liver histopathology [103]. It is thus obvious that more studies are needed in $\mathrm{HBeAg}(-)$ infection in order to establish a possible role for HBV RNA in serum for treatment monitoring.

\subsubsection{Predictive Biomarkers for the Response to Pegylated-Interferon}

Although only a limited number of HBeAg-negative patients receive pegylated-IFN (peg-IFN), several parameters have been identified as baseline predictors of response to this treatment. Younger age, female sex, higher ALT levels, and lower HBV DNA levels have been associated with greater probability of a sustained virological and biochemical response [104]. HBV genotypes appear to have an impact on sustained response (SR), with HBV genotype D infected patients being less likely to attain 
biochemical and virological remission enduring one year after treatment, compared to genotype $\mathrm{B}$ (odds ratio (OD): $3.69, p=0.003$ ) or genotype C (OD: 5.46, $p<0.001$ ). It is also known that treatment with peg-IFN induces a decrease in qHBsAg which is much greater than in NA treatment [105]. Furthermore, baseline pretreatment $\mathrm{qHBsAg}$ titer $<1250 \mathrm{IU} / \mathrm{mL}$ has also been associated with sustained off-treatment viral response [106].

On treatment monitoring of HBV DNA and HBsAg have been proven to be essential since the negative predictive value for SVR is $100 \%$ when no decrease in qHBsAg combined with HBV DNA decrease of less than $2 \log 10 \mathrm{IU} / \mathrm{mL}$ are noted at week 12 of treatment [107]. Thus, a stopping rule or motivation for continuing peg-IFN treatment has been established for HBeAg negative patients, based on qHBsAg and HBV DNA measurements at baseline and 12 weeks after the initiation of treatment [108]. Additionally, a second stopping rule at 24 weeks in cases of $\mathrm{HBsAg}>7500 \mathrm{IU} / \mathrm{mL}$ has been proposed to increase the cost effectiveness of treatment in HBeAg-negative patients with $\mathrm{E}$ genotype [109]. In a Greek study with patients infected with genotype D virus, a qHBsAg decline of greater than $10 \%$ at week 24 of peg-IFN treatment was associated with SR and when combined with the 12 week stopping rule almost two-thirds of patients who did not achieve SR could be identified [110].

In combination treatment with Peg-IFN and adefovir, $\mathrm{HBeAg}(-)$ patients who responded to therapy were shown to have lower HBV-RNA levels than non-responders at all time points, there was an independent association of low pretreatment HBV RNA and response to Peg-IFN and adefovir (OD: $0.44 ; p=0.019$ ) and an earlier and steeper HBV RNA decline in the group of responders $(p=0.028)[62]$.

\subsubsection{Predictive Biomarkers for Functional Cure with Nucleos(t)ide Analog Treatment}

The third generation NAs are potent and with high genetic barrier, therefore able in the majority of cases to lead to viral suppression with undetectable HBV DNA in serum. In this case, the prediction of NA treatment-related HBsAg clearance (the most closely related to cure outcome) has become an important issue, although it is rare and accomplished after long duration of therapy [111,112].

Absolute values of qHBsAg could be an important predictive marker in HBeAg(-) NA treated infection, as low levels at baseline $(<730-1000 \mathrm{IU} / \mathrm{mL})$ have been associated with functional cure $[113,114]$. Also, the kinetics of qHBsAg during NA treatment has been studied. An early decline in qHBsAg at six months of therapy [115], on-treatment yearly reductions $>0.166 \log$ IU $/ \mathrm{mL}$ [105], and a $>0.5 \log \mathrm{IU} / \mathrm{mL}$ drop in the two years after viral response [116] were found to be predictive of subsequent HBsAg clearance.

In a recent study, a qHBsAg reduction $>0.3 \log \mathrm{IU} / \mathrm{mL}$ in three years of NA treatment had positive and negative predictive values of $42 \%$ and $100 \%$ respectively, for the identification of patients achieving low levels of HBsAg $(<120 \mathrm{IU} / \mathrm{mL})$. The annual decline of qHBsAg was also greater in patients achieving low HBsAg levels $(-0.257)$ than in those who did not $(-0.057),(p<0.001)$. No baseline variables predicted functional cure under NA treatment [117].

\subsubsection{Predictive Biomarkers for Discontinuation of Nucleos(t)ide Analogs}

As stated in the recent EASL guidelines, NAs in $\mathrm{HBeAg}(-)$ patients should be administered long term until HBsAg loss, but in selected cases of non-cirrhotic patients stopping treatment could be considered after long term (>3 years) of on treatment complete viral response, but only if close post-NA monitoring is feasible [40]. According to previous guidelines of the Asian Pacific Association for the Study of the Liver (APASL), cessation of NAs can be considered in HBeAg(-) hepatitis, if HBV DNA has been undetectable on three separate measurements, each at least six months apart [118,119].

When NA treatment is discontinued, sustained off-therapy virological response is defined based on serum HBV DNA levels, which according to EASL 2017 guidelines should be less than $2000 \mathrm{IU} / \mathrm{mL}$ for at least 12 months after end of treatment (EOT). In the majority of the cases, after stopping NAs, HBV DNA becomes detectable in serum accompanied or not with increased aminotransferases. This flare can be benign, even beneficial and in fact, following cessation of NA therapy, a high percentage of 
patients achieve HBsAg clearance after a transient increase in ALT and/or detectable viremia [120-122]. This is probably due to the restoration of the immune system which becomes capable of clearing the replicating virus after the inhibition of the viral reverse transcriptase is withdrawn [123,124].

HBsAg levels at EOT appear to be an important predictor of HBsAg loss. In HBeAg negative patients $\mathrm{qHBsAg}<100 \mathrm{IU} / \mathrm{mL}$ at EOT has been found to be a significant independent factor for subsequent functional cure $[120,122,125]$. Moreover, it was recently suggested that close qHBsAg monitoring, at least every three months and more frequently according to ALT, after stopping NA therapy, is important for the differentiation of benign flare that could lead to HBsAg seroclearance, from a flare that would lead to further liver deterioration and needs to be treated. Decreasing qHBsAg after the ALT peak appears to be related with benign flares and in those patients re-treatment could be withheld [126].

On the other hand, prediction of virological and clinical relapse after NA discontinuation is also extremely valuable. In an Asian study [56], including $\mathrm{HBeAg}(-)$ patients, serum HBV RNA levels were found to be significantly associated with virological relapse after NA discontinuation. In one study that included 33 patients who discontinued NA treatment after a long period of undetectable serum HBV DNA, it was found that at the EOT 21 patients (63.64\%) were serum HBV RNA positive. Viral relapse was seen in $21(100 \%)$ of the HBV RNA positive versus $3(25 \%)$ of the 12 patients with undetectable HBV RNA at the EOT ( $p=0.001)$ [63]. Although these results are promising, it needs to be noted that the majority of $\mathrm{HBeAg}(-)$ patients under effective NA treatment become serum HBV RNA negative [62]. Nevertheless, it appears that serum HBV RNA may prove to be a predictive biomarker for the safe discontinuation of NA therapy, primarily as an indicator of virological and possibly clinical relapse, since the detection HBV RNA in serum is associated with the risk of viral rebound.

\subsection{Hepatocellular Carcinoma}

Hepatocellular carcinoma (HCC) is a frequent and life-threatening complication of HBV chronic infection even in HBe antigen negative phases [127]. Liver cirrhosis and HBV viremia (positive HBV DNA) are the critical factors for the development of HCC in chronically infected individuals, even on long-term antiviral treatment [128]. In fact, low level viremia $(<2000 \mathrm{IU} / \mathrm{mL})$ under treatment with potent NAs has been associated with a higher risk of HCC than in maintained complete virological response (HR 1.98, 95\% CI 1.28-3.06, $p=0.002$ ) [129].

Although in cases of HCC, serum HBV DNA levels do not have a strong association with intrahepatic viral load, which also differs between the areas of tumor and surrounding non tumor tissue [130], the level of HBV viremia has been shown to be an independent HCC risk factor (HBV DNA $\geq 5.0$ vs. $<5$ log IU /mL, HR 3.78, 95\% CI 1.20-11.9, $p<0.02$ ) [131].

In a relatively recent meta-analysis, high qHBsAg was found to be associated with HCC. Unfortunately, pooled data from only two studies that fulfilled the criteria were used and showed that the risk of HCC occurrence in patients with high HBsAg levels compared to low HBsAg levels $[132,133]$ was significant (OR: 2.21; 95\% CI, 1.52-3.22; $p<0.01$ ) [134].

More recently, in a group of $\mathrm{CHB}$ patients who were not treated with NAs several viral biomarkers including HBV DNA, HBV genotype and $\mathrm{HBcrAg}$, but not qHBsAg, were found to be associated with the incidence of HCC. Specifically, HBcrAg was independently associated with HCC development at levels $>2.9 \log \mathrm{U} / \mathrm{mL}$ (HR, 5.05; 95\% confidence interval (CI), 2.40-10.63) was better predictive marker than HBV DNA [135]. In another study involving patients with undetectable HBV DNA due to effective antiviral therapy, $\mathrm{HBcrAg} \geq 7.8 \mathrm{kU} / \mathrm{mL}$ was also found to be predictive for HCC with OR 3.27 in the total group and higher at 5.95 in non cirrhotics [136].

\subsection{Future Therapies and Viral Biomarkers}

Current treatment of HBeAg negative chronic hepatitis with potent NAs with high genetic barrier for resistance, is highly effective in terms of viral suppression but does not lead to viral elimination. New drugs and therapeutic strategies are emerging that target different steps of the virus life cycle 
and enhance the immune response against HBV, aiming at complete viral clearance [137]. It is obvious that treatment monitoring and evaluation of response to future therapies would require increased sensitivity of the current assays of viral molecular markers, for a negative result to reflect complete viral eradication from the liver. Moreover, according to the mode of action of the drug (inhibition of viral entry, capsid formation, gene expression, cccDNA formation and stability, etc.) [138] it is possible that other drug specific viral biomarkers will emerge.

\section{Conclusions}

Viral specific biomarkers are used for the diagnosis and monitoring of HBeAg negative hepatitis. Serology and HBV DNA quantification are the established and widely used tests. The implementation of HBsAg quantification is expanding for monitoring the disease in its natural course and on treatment. Other biomarkers, including HBcrAg and HBV RNA, are still under evaluation.

Funding: This work received no external funding.

Conflicts of Interest: The authors declare no conflict of interest.

\section{References}

1. World Health Organization (WHO). Global Hepatitis Report. 2017. Available online: www.who.int/ hepatitis/publications/global-hepatitis-report2017 (accessed on 1 August 2018).

2. Villar, L.M.; Cruz, H.M.; Barbosa, J.R.; Bezerra, C.S.; Portilho, M.M.; Scalioni, L.P. Update on hepatitis B and C virus diagnosis. World J. Virol. 2015, 4, 323-342. [CrossRef] [PubMed]

3. Osiowy, C.; Coffin, C.; Andonov, A. Review of Laboratory Tests used in Monitoring Hepatitis B Response to Pegylated Interferon and Nucleos(t)ide Analog Therapy. Curr. Treat. Options Infect. Dis. 2016, 8, 177-193. [CrossRef] [PubMed]

4. Song, J.E.; Kim, D.Y. Diagnosis of hepatitis B. Ann. Transl. Med. 2016, 4, 338. [CrossRef] [PubMed]

5. Blumberg, B.S.; Alter, H.J.; Visnich, S. A "new" antigen in leukemia sera. JAMA 1965, 191, 541-546. [CrossRef] [PubMed]

6. $\quad$ Dienes, H.P.; Gerlich, W.H.; Worsdorfer, M.; Gerken, G.; Bianchi, L.; Hess, G.; Meyer Zum Büschenfelde, K.-H. Hepatic expression patterns of the large and middle hepatitis $B$ virus surface proteins in viremic and nonviremic chronic hepatitis B. Gastroenterology 1990, 98, 1017-1023. [CrossRef]

7. Shinkai, N.; Matsuura, K.; Sugauchi, F.; Watanabe, T.; Murakami, S.; Iio, E.; Ogawa, S.; Nojiri, S.; Joh, T.; Tanaka, Y. Application of a newly developed high-sensitivity HBsAg chemiluminescent enzyme immunoassay for hepatitis B patients with HBsAg seroclearance. J. Clin. Microbiol. 2013, 51, 3484-3491. [CrossRef] [PubMed]

8. Sommese, L.; Sabia, C.; Paolillo, R.; Parente, D.; Capuano, M.; Iannone, C.; Cavalca, F.; Schiano, C.; Vasco, M.; De Pascale, M.R.; et al. Screening tests for hepatitis B virus, hepatitis $C$ virus, and human immunodeficiency virus in blood donors: Evaluation of two chemiluminescent immunoassay systems. Scand. J. Infect. Dis. 2014, 46, 660-664. [CrossRef] [PubMed]

9. Chu, F.Y.; Su, F.H.; Cheng, S.H.; Lin, Y.S.; Li, C.Y.; Chien, C.C.; Lin, Y.C.; Chiang, S.Y. Hepatitis B surface antigen confirmatory testing for diagnosis of hepatitis B virus infection in Taiwan. J. Med. Virol. 2011, 83, 1514-1521. [CrossRef] [PubMed]

10. Van Helden, J.; Cornely, C.; Dati, F.; Levy, H.R.; Bal, T.; Seeger, M.; Wright, T.; Baker, L. Performance evaluation of the ADVIA Centaur anti-HBe and HBeAg assays. J. Clin. Virol. 2008, 43, 169-175. [CrossRef] [PubMed]

11. Feng, S.; Wei, B.; Rao, C.; Wang, T.; Xiao, Y.; Tao, C.; Wang, L. Clinical evaluation of the newly developed HISCL-5000 analyzer on detection of hepatitis B virus markers in West China hospital. Clin. Lab. 2016, 62, 1053-1060. [CrossRef] [PubMed]

12. Choi, S.J.; Park, Y.; Lee, E.Y.; Kim, S.; Kim, H.S. Performance evaluation of LUMIPULSE G1200 autoimmunoanalyzer for the detection of serum hepatitis B virus markers. J. Clin. Lab. Anal. 2013, 27, 204-206. [CrossRef] [PubMed] 
13. Xu, W.Z.; Li, Y.; Wu, Q.; Wang, M.; Wu, Z. Brief communication: Comparison the diagnostic performance of four HBsAg ELISA kits. J. Clin. Lab. Anal. 2013, 27, 294-296.

14. Xu, L.; Yu, Z.; Fan, W.; Wang, X.; Xie, M.; Xu, Y.; Hu, L.; Li, Y. Negative interference in serum HBsAg ELISA from rheumatoid factors. PLoS ONE 2013, 8, e80620. [CrossRef] [PubMed]

15. Xu, W.; Li, Y.; Wang, M.; Gu, J. Comparison of two immunoassays for determining hepatitis B virus serum markers. Clin. Chem. Lab. Med. 2011, 50, 153-157. [CrossRef] [PubMed]

16. Pai, N.P.; Dhurat, R.; Potter, M.; Behlim, T.; Landry, G.; Vadnais, C.; Rodrigues, C.; Joseph, L.; Shetty, A. Will a quadruple multiplexed point-of-care screening strategy for HIV-related co-infections be feasible and impact detection of new co-infections in at-risk populations? Results from cross-sectional studies. BMJ Open 2014, 4, e005040. [CrossRef] [PubMed]

17. Bottero, J.; Boyd, A.; Gozlan, J.; Lemoine, M.; Carrat, F.; Collignon, A.; Boo, N.; Dhotte, P.; Varsat, B.; Muller, G.; et al. Performance of rapid tests for detection of HBsAg and anti-HBsAb in a large cohort, France. J. Hepatol. 2013, 58, 473-478. [CrossRef] [PubMed]

18. Perrillo, R.; Campbell, C.; Wellinghoff, W.; Gelb, L. The relationship of hepatitis B e antigen, DNA polymerase activity, and titer of hepatitis B surface antigen with ongoing liver injury in chronic hepatitis B virus infection. Am. J. Gastroenterol. 1982, 77, 445-449. [PubMed]

19. Liao, C.C.; Hsu, C.W.; Gu, P.W.; Yeh, C.T.; Lin, S.M.; Chiu, C.T. Comparison of the elecsys HBsAg II assay and the architect assay for quantification of hepatitis B surface antigen in chronic hepatitis B patients. Biomed. J. 2015, 38, 250-256. [PubMed]

20. Yang, R.; Song, G.; Guan, W.; Wang, Q.; Liu, Y.; Wei, L. The Lumipulse G HBsAg-Quant assay for screening and quantification of the hepatitis B surface antigen. J. Virol. Methods 2016, 228, 39-47. [CrossRef] [PubMed]

21. Hadziyannis, E.; Hadziyannis, S.J. Hepatitis B surface antigen quantification in chronic hepatitis B and its clinical utility. Expert Rev. Gastroenterol. Hepatol. 2014, 8, 185-195. [CrossRef] [PubMed]

22. Maylin, S.; Boyd, A.; Martinot-Peignoux, M.; Delaugerre, C.; Bagnard, G.; Lapalus, M.; Zoulim, F.; Lavocat, F.; Marcellin, P.; Simon, F.; et al. Quantification of hepatitis B e antigen between Elecsys HBeAg and Architect HBeAg assays among patients infected with hepatitis B virus. J. Clin. Virol. 2013, 56, 306-311. [CrossRef] [PubMed]

23. Fried, M.W.; Piratvisuth, T.; Lau, G.K.; Marcellin, P.; Chow, W.C.; Cooksley, G.; Luo, K.X.; Paik, S.W.; Liaw, Y.F.; Button, P.; et al. HBeAg and hepatitis B virus DNA as outcome predictors during therapy with peginterferon alfa-2a for HBeAg-positive chronic hepatitis B. Hepatology 2008, 47, 428-434. [CrossRef] [PubMed]

24. Ma, H.; Yang, R.F.; Wei, L. Quantitative serum HBsAg and HBeAg are strong predictors of sustained HBeAg seroconversion to pegylated interferon alfa-2b in HBeAg-positive patients. J. Gastroenterol. Hepatol 2010, 25, 1498-1506. [CrossRef] [PubMed]

25. Zhang, X.; Lin, S.M.; Ye, F.; Chen, T.Y.; Liu, M.; Chen, Y.R.; Zheng, S.Q.; Zhao, Y.R.; Zhang, S.L. An early decrease in serum HBeAg titre is a strong predictor of virological response to entecavir in HBeAg-positive patients. J. Viral Hepat. 2011, 18, e184-e190. [CrossRef] [PubMed]

26. Buster, E.H.; Flink, H.J.; Cakaloglu, Y.; Simon, K.; Trojan, J.; Tabak, F.; So, T.M.; Feinman, S.V.; Mach, T.; Akarca, U.S.; et al. Sustained HBeAg and HBsAg loss after long-term follow-up of HBeAg-positive patients treated with peginterferon alpha-2b. Gastroenterology 2008, 135, 459-467. [CrossRef] [PubMed]

27. Wursthorn, K.; Zacher, B.J.; Jaroszewicz, J.; Darnedde, M.; Manns, M.; Wedemeyer, H. Development of a protocol for the quantitative determination of HBeAg using the Elecsys(R) HBeAg immunoassay. J. Viral Hepat. 2011, 18, e179-e183. [CrossRef] [PubMed]

28. Rokuhara, A.; Tanaka, E.; Matsumoto, A.; Kimura, T.; Yamaura, T.; Orii, K.; Sun, X.; Yagi, S.; Maki, N.; Kiyosawa, K. Clinical evaluation of a new enzyme immunoassay for hepatitis B virus core-related antigen; a marker distinct from viral DNA for monitoring lamivudine treatment. J. Viral Hepat. 2003, 10, 324-330. [CrossRef] [PubMed]

29. Wong, D.K.; Tanaka, Y.; Lai, C.L.; Mizokami, M.; Fung, J.; Yuen, M.F. Hepatitis B virus core-related antigens as markers for monitoring chronic hepatitis B infection. J. Clin. Microbiol. 2007, 45, 3942-3947. [CrossRef] [PubMed]

30. Maasoumy, B.; Wiegand, S.B.; Jaroszewicz, J.; Bremer, B.; Lehmann, P.; Deterding, K.; Taranta, A.; Manns, M.P.; Wedemeyer, H.; Glebe, D.; et al. Hepatitis B core-related antigen (HBcrAg) levels in the natural history of hepatitis B virus infection in a large European cohort predominantly infected with genotypes A and D. Clin. Microbiol. Infect. 2015, 21, 606-610. [CrossRef] [PubMed] 
31. Seto, W.K.; Wong, D.K.; Fung, J.; Huang, F.Y.; Liu, K.S.; Lai, C.L.; Yuen, M.F. Linearized hepatitis B surface antigen and hepatitis B core-related antigen in the natural history of chronic hepatitis B. Clin. Microbiol Infect. 2014, 20, 1173-1180. [CrossRef] [PubMed]

32. Suzuki, F.; Miyakoshi, H.; Kobayashi, M.; Kumada, H. Correlation between serum hepatitis B virus core-related antigen and intrahepatic covalently closed circular DNA in chronic hepatitis B patients. J. Med. Virol. 2009, 81, 27-33. [CrossRef] [PubMed]

33. Lok, A.S.; Hadziyannis, S.J.; Weller, I.V.; Karvountzis, M.G.; Monjardino, J.; Karayiannis, P.; Montano, L.; Thomas, H.C. Contribution of low level HBV replication to continuing inflammatory activity in patients with anti-HBe positive chronic hepatitis B virus infection. Gut 1984, 25, 1283-1287. [CrossRef] [PubMed]

34. Karayiannis, P.; Fowler, M.J.; Lok, A.S.; Greenfield, C.; Monjardino, J.; Thomas, H.C. Detection of serum HBV-DNA by molecular hybridisation. Correlation with HBeAg/anti-HBe status, racial origin, liver histology and hepatocellular carcinoma. J. Hepatol. 1985, 1, 99-106. [CrossRef]

35. Chu, C.M.; Karayiannis, P.; Fowler, M.J.; Monjardino, J.; Liaw, Y.F.; Thomas, H.C. Natural history of chronic hepatitis B virus infection in Taiwan: Studies of hepatitis B virus DNA in serum. Hepatology 1985, 5, 431-434. [CrossRef] [PubMed]

36. Kim, H.; Hur, M.; Bae, E.; Lee, K.A.; Lee, W.I. Performance evaluation of cobas HBV real-time PCR assay on Roche cobas 4800 System in comparison with COBAS AmpliPrep/COBAS TaqMan HBV Test. Clin. Chem. Lab. Med. 2018, 56, 1133-1139. [CrossRef] [PubMed]

37. Morris, C.J.; Hill, M.; de Medina, M.; Herman, C.; Cloherty, G.A.; Martin, P. Comparison of detection and quantification of HBV DNA in chronic HBeAg negative and positive patients by Abbott RealTime HBV and Roche Cobas TaqMan HBV assays. J. Virol. Methods 2013, 193, 391-393. [CrossRef] [PubMed]

38. Peeling, R.W.; Boeras, D.I.; Marinucci, F.; Easterbrook, P. The future of viral hepatitis testing: Innovations in testing technologies and approaches. BMC Infect. Dis. 2017, 17, 699. [CrossRef] [PubMed]

39. Terrault, N.A.; Bzowej, N.H.; Chang, K.M.; Hwang, J.P.; Jonas, M.M.; Murad, M.H. AASLD guidelines for treatment of chronic hepatitis B. Hepatology 2016, 63, 261-283. [CrossRef] [PubMed]

40. European Association for the Study of the Liver. EASL 2017 Clinical Practice Guidelines on the management of hepatitis B virus infection. J. Hepatol. 2017, 67, 370-398. [CrossRef] [PubMed]

41. Liu, C.; Chang, L.; Jia, T.; Guo, F.; Zhang, L.; Ji, H.; Zhao, J.; Wang, L. Real-time PCR assays for hepatitis B virus DNA quantification may require two different targets. Virol. J. 2017, 14, 94. [CrossRef] [PubMed]

42. Lange, B.; Roberts, T.; Cohn, J.; Greenman, J.; Camp, J.; Ishizaki, A.; Messac, L.; Tuaillon, E.; van de Perre, P.; Pichler, C.; et al. Diagnostic accuracy of detection and quantification of HBV-DNA and HCV-RNA using dried blood spot (DBS) samples-A systematic review and meta-analysis. BMC Infect. Dis. 2017, 17, 693. [CrossRef] [PubMed]

43. Portilho, M.M.; Mendonca, A.C.D.F.; Bezerra, C.S.; do Espirito-Santo, M.P.; de Paula, V.S.; Nabuco, L.C.; Villela-Nogueira, C.A.; Lewis-Ximenez, L.L.; Lampe, E.; Villar, L.M. Usefulness of in-house real time PCR for HBV DNA quantification in serum and oral fluid samples. J. Virol. Methods 2018, 256, 100-106. [CrossRef] [PubMed]

44. Portilho, M.M.; Martins, P.P.; Lampe, E.; Villar, L.M. A comparison of molecular methods for hepatitis B virus (HBV) DNA detection from oral fluid samples. J. Med. Microbiol. 2012, 61, 844-851. [CrossRef] [PubMed]

45. Heiberg, I.L.; Hoegh, M.; Ladelund, S.; Niesters, H.G.; Hogh, B. Hepatitis B virus DNA in saliva from children with chronic hepatitis B infection: Implications for saliva as a potential mode of horizontal transmission. Pediatr. Infect. Dis. J. 2010, 29, 465-467. [CrossRef] [PubMed]

46. Van der Eijk, A.A.; Niesters, H.G.; Hansen, B.E.; Pas, S.D.; Richardus, J.H.; Mostert, M.; Janssen, H.L.; Schalm, S.W.; de Man, R.A. Paired, quantitative measurements of hepatitis B virus DNA in saliva, urine and serum of chronic hepatitis B patients. Eur. J. Gastroenterol. Hepatol. 2005, 17, 1173-1179. [CrossRef] [PubMed]

47. Huang, J.T.; Yang, Y.; Hu, Y.M.; Liu, X.H.; Liao, M.Y.; Morgan, R.; Yuan, E.F.; Li, X.; Liu, S.M. A Highly Sensitive and Robust Method for Hepatitis B Virus Covalently Closed Circular DNA Detection in Single Cells and Serum. J. Mol. Diagn. 2018, 20, 334-343. [CrossRef] [PubMed]

48. Zhang, Z.H.; Wu, C.C.; Chen, X.W.; Li, X.; Li, J.; Lu, M.J. Genetic variation of hepatitis B virus and its significance for pathogenesis. World J. Gastroenterol. 2016, 22, 126-144. [CrossRef] [PubMed]

49. Schaefer, S. Hepatitis B virus taxonomy and hepatitis B virus genotypes. World J. Gastroenterol. 2007, 13, 14-21. [CrossRef] [PubMed] 
50. Guirgis, B.S.; Abbas, R.O.; Azzazy, H.M. Hepatitis B virus genotyping: Current methods and clinical implications. Int. J. Infect. Dis. 2010, 14, e941-e953. [CrossRef] [PubMed]

51. Osiowy, C.; Giles, E. Evaluation of the INNO-LiPA HBV genotyping assay for determination of hepatitis B virus genotype. J. Clin. Microbiol. 2003, 41, 5473-5477. [CrossRef] [PubMed]

52. Carman, W.F.; Jacyna, M.R.; Hadziyannis, S.; Karayiannis, P.; McGarvey, M.J.; Makris, A.; Thomas, H.C. Mutation preventing formation of hepatitis B e antigen in patients with chronic hepatitis B infection. Lancet 1989, 2, 588-591. [CrossRef]

53. Lindh, M.; Andersson, A.S.; Gusdal, A. Genotypes, nt 1858 variants, and geographic origin of hepatitis B virus-large-scale analysis using a new genotyping method. J. Infect. Dis. 1997, 175, 1285-1293. [CrossRef] [PubMed]

54. Basaras, M.; Arrese, E.; Blanco, S.; Arroyo, L.S.; Ruiz, P.; Cisterna, R. Comparison of INNO-LIPA and TRUGENE assays for genotyping and drug-resistance mutations in chronic hepatitis B virus infection. Intervirology 2013, 56, 190-194. [CrossRef] [PubMed]

55. Hatakeyama, T.; Noguchi, C.; Hiraga, N.; Mori, N.; Tsuge, M.; Imamura, M.; Takahashi, S.; Kawakami, Y.; Fujimoto, Y.; Ochi, H.; et al. Serum HBV RNA is a predictor of early emergence of the YMDD mutant in patients treated with lamivudine. Hepatology 2007, 45, 1179-1186. [CrossRef] [PubMed]

56. Tsuge, M.; Murakami, E.; Imamura, M.; Abe, H.; Miki, D.; Hiraga, N.; Takahashi, S.; Ochi, H.; Nelson, H.C.; Ginba, H.; et al. Serum HBV RNA and HBeAg are useful markers for the safe discontinuation of nucleotide analog treatments in chronic hepatitis B patients. J. Gastroenterol. 2013, 48, 1188-1204. [CrossRef] [PubMed]

57. Huang, Y.W.; Takahashi, S.; Tsuge, M.; Chen, C.L.; Wang, T.C.; Abe, H.; Hu, J.T.; Chen, D.S.; Yang, S.S.; Chayama, K.; et al. On-treatment low serum HBV RNA level predicts initial virological response in chronic hepatitis B patients receiving nucleoside analog therapy. Antivir. Ther. 2015, 20, 369-375. [CrossRef] [PubMed]

58. Van Bommel, F.; van Bömmel, A.; Krauel, A.; Wat, C.; Pavlovic, V.; Yang, L.; Deichsel, D.; Berg, T.; Bohm, S. Serum HBV RNA as a Predictor of Peginterferon Alfa-2a (40KD) Response in Patients with HBeAg-Positive Chronic Hepatitis B. J. Infect. Dis. 2018, 218, 1066-1074. [CrossRef] [PubMed]

59. Rokuhara, A.; Matsumoto, A.; Tanaka, E.; Umemura, T.; Yoshizawa, K.; Kimura, T.; Maki, N.; Kiyosawa, K. Hepatitis B virus RNA is measurable in serum and can be a new marker for monitoring lamivudine therapy. J. Gastroenterol. 2006, 41, 785-790. [CrossRef] [PubMed]

60. Kock, J.; Theilmann, L.; Galle, P.; Schlicht, H.J. Hepatitis B virus nucleic acids associated with human peripheral blood mononuclear cells do not originate from replicating virus. Hepatology 1996, 23, $405-413$. [PubMed]

61. Su, Q.; Wang, S.F.; Chang, T.E.; Breitkreutz, R.; Hennig, H.; Takegoshi, K.; Edler, L.; Schroder, C.H. Circulating hepatitis B virus nucleic acids in chronic infection : Representation of differently polyadenylated viral transcripts during progression to nonreplicative stages. Clin. Cancer Res. 2001, 7, 2005-2015. [PubMed]

62. Jansen, L.; Kootstra, N.A.; van Dort, K.A.; Takkenberg, R.B.; Reesink, H.W.; Zaaijer, H.L. Hepatitis B Virus Pregenomic RNA Is Present in Virions in Plasma and Is Associated With a Response to Pegylated Interferon Alfa-2a and Nucleos(t)ide Analogs. J. Infect. Dis. 2016, 213, 224-232. [CrossRef] [PubMed]

63. Wang, J.; Shen, T.; Huang, X.; Kumar, G.R.; Chen, X.; Zeng, Z.; Zhang, R.; Chen, R.; Li, T.; Zhang, T.; et al. Serum hepatitis B virus RNA is encapsidated pregenome RNA that may be associated with persistence of viral infection and rebound. J. Hepatol. 2016, 65, 700-710. [CrossRef] [PubMed]

64. Zhang, W.; Hacker, H.J.; Tokus, M.; Bock, T.; Schroder, C.H. Patterns of circulating hepatitis B virus serum nucleic acids during lamivudine therapy. J. Med. Virol. 2003, 71, 24-30. [CrossRef] [PubMed]

65. Van Bommel, F.; Bartens, A.; Mysickova, A.; Hofmann, J.; Kruger, D.H.; Berg, T.; Edelmann, A. Serum hepatitis B virus RNA levels as an early predictor of hepatitis B envelope antigen seroconversion during treatment with polymerase inhibitors. Hepatology 2015, 61, 66-76. [CrossRef] [PubMed]

66. Lam, A.M.; Ren, S.; Espiritu, C.; Kelly, M.; Lau, V.; Zheng, L.; Hartman, G.D.; Flores, O.A.; Klumpp, K. Hepatitis B Virus Capsid Assembly Modulators, but Not Nucleoside Analogs, Inhibit the Production of Extracellular Pregenomic RNA and Spliced RNA Variants. Antimicrob. Agents Chemother. 2017, 61, e00680-17. [CrossRef] [PubMed]

67. Niu, C.; Livingston, C.M.; Li, L.; Beran, R.K.; Daffis, S.; Ramakrishnan, D.; Burdette, D.; Peiser, L.; Salas, E.; Ramos, H.; et al. The Smc5/6 Complex Restricts HBV when Localized to ND10 without Inducing an Innate 
Immune Response and Is Counteracted by the HBV X Protein Shortly after Infection. PLoS ONE 2017, 12, e0169648. [CrossRef] [PubMed]

68. Castillo, I.; Rodriguez-Inigo, E.; Lopez-Alcorocho, J.M.; Bartolome, J.; Pardo, M.; Carreno, V. Comparative study on the clinical and virological characteristics among patients with single occult hepatitis B virus (HBV), single occult hepatitis $\mathrm{C}$ virus (HCV) and occult HBV and HCV dual infection. J. Med. Virol. 2007, 79, 236-241. [CrossRef] [PubMed]

69. Gonzalez, R.; Torres, P.; Castro, E.; Barbolla, L.; Candotti, D.; Koppelman, M.; Zaaijer, H.L.; Lelie, N.; Allain, J.P.; Echevarria, J.M. Efficacy of hepatitis B virus (HBV) DNA screening and characterization of acute and occult HBV infections among blood donors from Madrid, Spain. Transfusion 2010, 50, 221-230. [CrossRef] [PubMed]

70. Izmirli, S.; Celik, D.G.; Yuksel, P.; Saribas, S.; Aslan, M.; Ergin, S.; Bahar, H.; Sen, S.; Cakal, B.; Oner, A.; et al. The detection of occult HBV infection in patients with HBsAg negative pattern by real-time PCR method. Transfus. Apher. Sci. 2012, 47, 283-287. [CrossRef] [PubMed]

71. Raimondo, G.; Caccamo, G.; Filomia, R.; Pollicino, T. Occult HBV infection. Semin. Immunopathol. 2013, 35, 39-52. [CrossRef] [PubMed]

72. Ponde, R.A. Molecular mechanisms underlying HBsAg negativity in occult HBV infection. Eur. J. Clin. Microbiol. Infect. Dis. 2015, 34, 1709-1731. [CrossRef] [PubMed]

73. Coppola, N.; Onorato, L.; Iodice, V.; Starace, M.; Minichini, C.; Farella, N.; Liorre, G.; Filippini, P.; Sagnelli, E.; de Stefano, G. Occult HBV infection in HCC and cirrhotic tissue of HBsAg-negative patients: A virological and clinical study. Oncotarget 2016, 7, 62706-62714. [CrossRef] [PubMed]

74. Koutsianas, C.; Thomas, K.; Vassilopoulos, D. Hepatitis B Reactivation in Rheumatic Diseases: Screening and Prevention. Rheum. Dis. Clin. N. Am. 2017, 43, 133-149. [CrossRef] [PubMed]

75. Calabrese, L.H.; Zein, N.N.; Vassilopoulos, D. Hepatitis B virus (HBV) reactivation with immunosuppressive therapy in rheumatic diseases: Assessment and preventive strategies. Ann. Rheum. Dis. 2006, 65, 983-989. [CrossRef] [PubMed]

76. Terrault, N.A.; Lok, A.S.F.; McMahon, B.J.; Chang, K.M.; Hwang, J.P.; Jonas, M.M.; Brown, R.S., Jr.; Bzowej, N.H.; Wong, J.B. Update on prevention, diagnosis, and treatment of chronic hepatitis B: AASLD 2018 hepatitis B guidance. Hepatology 2018, 67, 1560-1599. [CrossRef] [PubMed]

77. Jaroszewicz, J.; Calle, S.B.; Wursthorn, K.; Deterding, K.; Schlue, J.; Raupach, R.; Flisiak, R.; Bock, C.T.; Manns, M.P.; Wedemeyer, H.; et al. Hepatitis B surface antigen (HBsAg) levels in the natural history of hepatitis B virus (HBV)-infection: A European perspective. J. Hepatol. 2010, 52, 514-522. [CrossRef] [PubMed]

78. Nguyen, T.; Thompson, A.J.; Bowden, S.; Croagh, C.; Bell, S.; Desmond, P.V.; Levy, M.; Locarnini, S.A. Hepatitis B surface antigen levels during the natural history of chronic hepatitis B: A perspective on Asia. J. Hepatol. 2010, 52, 508-513. [CrossRef] [PubMed]

79. Brunetto, M.R.; Oliveri, F.; Colombatto, P.; Moriconi, F.; Ciccorossi, P.; Coco, B.; Romagnoli, V.; Cherubini, B.; Moscato, G.; Maina, A.M.; et al. Hepatitis B surface antigen serum levels help to distinguish active from inactive hepatitis B virus genotype D carriers. Gastroenterology 2010, 139, 483-490. [CrossRef] [PubMed]

80. Tseng, T.C.; Liu, C.J.; Yang, H.C.; Su, T.H.; Wang, C.C.; Chen, C.L.; Kuo, S.F.; Liu, C.H.; Chen, P.J.; Chen, D.S.; et al. Determinants of spontaneous surface antigen loss in hepatitis $\mathrm{B}$ e antigen-negative patients with a low viral load. Hepatology 2012, 55, 68-76. [CrossRef] [PubMed]

81. Liu, J.; Yang, H.I.; Lee, M.H.; Jen, C.L.; Batrla-Utermann, R.; Lu, S.N.; Wang, L.Y.; You, S.L.; Chen, C.J. Serum Levels of Hepatitis B Surface Antigen and DNA Can Predict Inactive Carriers With Low Risk of Disease Progression. Hepatology 2016, 64, 381-389. [CrossRef] [PubMed]

82. Sali, S.; Sharafi, H.; Alavian, S.H.; Alavian, S.M.; Etesam, F.; Salimi, S.; Merza, M.A.; Keshvari, M. Can serum level of HBsAg differentiate HBeAg-negative chronic hepatitis B from inactive carrier state? Diagn. Microbiol. Infect. Dis. 2015, 82, 114-119. [CrossRef] [PubMed]

83. Brouwer, W.P.; Chan, H.L.; Brunetto, M.R.; Martinot-Peignoux, M.; Arends, P.; Cornberg, M.; Cherubini, B.; Thompson, A.J.; Liaw, Y.F.; Marcellin, P.; et al. Repeated Measurements of Hepatitis B Surface Antigen Identify Carriers of Inactive HBV During Long-term Follow-up. Clin. Gastroenterol. Hepatol. 2016, 14, 1481-1489. [CrossRef] [PubMed]

84. Maimone, S.; Caccamo, G.; Squadrito, G.; Alibrandi, A.; Saffioti, F.; Spinella, R.; Raffa, G.; Pollicino, T.; Raimondo, G. A combination of different diagnostic tools allows identification of inactive hepatitis $B$ virus carriers at a single time point evaluation. Liver Int. 2017, 37, 362-368. [CrossRef] [PubMed] 
85. Riveiro-Barciela, M.; Bes, M.; Rodriguez-Frias, F.; Tabernero, D.; Ruiz, A.; Casillas, R.; Vidal-Gonzalez, J.; Homs, M.; Nieto, L.; Sauleda, S.; et al. Serum hepatitis B core-related antigen is more accurate than hepatitis B surface antigen to identify inactive carriers, regardless of hepatitis B virus genotype. Clin. Microbiol. Infect. 2017, 23, 860-867. [CrossRef] [PubMed]

86. Oliveri, F.; Surace, L.; Cavallone, D.; Colombatto, P.; Ricco, G.; Salvati, N.; Coco, B.; Romagnoli, V.; Gattai, R.; Salvati, A.; et al. Long-term outcome of inactive and active, low viraemic HBeAg-negative-hepatitis B virus infection: Benign course towards HBsAg clearance. Liver Int. 2017, 37, 1622-1631. [CrossRef] [PubMed]

87. Van Campenhout, M.J.H.; van, B.F.; Pfefferkorn, M.; Fischer, J.; Deichsel, D.; Boonstra, A.; van Vuuren, A.J.; Berg, T.; Hansen, B.E.; Janssen, H.L.A. Host and viral factors associated with serum hepatitis B virus RNA levels among patients in need for treatment. Hepatology 2018, 68, 839-847. [CrossRef] [PubMed]

88. Wang, J.; Yu, Y.; Li, G.; Shen, C.; Li, J.; Chen, S.; Zhang, X.; Zhu, M.; Zheng, J.; Song, Z.; et al. Natural history of serum HBV-RNA in chronic HBV infection. J. Viral Hepat. 2018, 25, 1038-1047. [CrossRef] [PubMed]

89. Wang, J.; Du, M.; Huang, H.; Chen, R.; Niu, J.; Jiang, J.; Zhuang, H.; Lu, F. Reply to: “Serum HBV pgRNA as a clinical marker for cccDNA activity": Consistent loss of serum HBV RNA might predict the "para-functional cure" of chronic hepatitis B. J. Hepatol. 2017, 66, 462-463. [CrossRef] [PubMed]

90. Huang, H.; Wang, J.; Li, W.; Chen, R.; Chen, X.; Zhang, F.; Xu, D.; Lu, F. Serum HBV DNA plus RNA shows superiority in reflecting the activity of intrahepatic cccDNA in treatment-naive HBV-infected individuals. J. Clin. Virol. 2018, 99-100, 71-78. [CrossRef] [PubMed]

91. Chu, C.M.; Liaw, Y.F. HBsAg seroclearance in asymptomatic carriers of high endemic areas: Appreciably high rates during a long-term follow-up. Hepatology 2007, 45, 1187-1192. [CrossRef] [PubMed]

92. Liu, J.; Yang, H.I.; Lee, M.H.; Lu, S.N.; Jen, C.L.; Wang, L.Y.; You, S.L.; Iloeje, U.H.; Chen, C.J. Incidence and determinants of spontaneous hepatitis B surface antigen seroclearance: A community-based follow-up study. Gastroenterology 2010, 139, 474-482. [CrossRef] [PubMed]

93. Tseng, T.C.; Liu, C.J.; Su, T.H.; Wang, C.C.; Chen, C.L.; Chen, P.J.; Chen, D.S.; Kao, J.H. Serum hepatitis B surface antigen levels predict surface antigen loss in hepatitis B e antigen seroconverters. Gastroenterology 2011, 141, 517-525. [CrossRef] [PubMed]

94. Chan, H.L.; Wong, G.L.; Tse, C.H.; Chan, H.Y.; Wong, V.W. Viral determinants of hepatitis B surface antigen seroclearance in hepatitis B e antigen-negative chronic hepatitis B patients. J. Infect. Dis. 2011, 204, 408-414. [CrossRef] [PubMed]

95. Seto, W.K.; Wong, D.K.; Fung, J.; Hung, I.F.; Fong, D.Y.; Yuen, J.C.; Tong, T.; Lai, C.L.; Yuen, M.F. A large case-control study on the predictability of hepatitis B surface antigen levels three years before hepatitis B surface antigen seroclearance. Hepatology 2012, 56, 812-819. [CrossRef] [PubMed]

96. Han, Z.G.; Qie, Z.H.; Qiao, W.Z. HBsAg spontaneous seroclearance in a cohort of HBeAg-seronegative patients with chronic hepatitis B virus infection. J. Med. Virol. 2016, 88, 79-85. [CrossRef] [PubMed]

97. Liu, J.; Lee, M.H.; Batrla-Utermann, R.; Jen, C.L.; Iloeje, U.H.; Lu, S.N.; Wang, L.Y.; You, S.L.; Hsiao, C.K.; Yang, H.I.; et al. A predictive scoring system for the seroclearance of HBsAg in HBeAg-seronegative chronic hepatitis B patients with genotype B or C infection. J. Hepatol. 2013, 58, 853-860. [CrossRef] [PubMed]

98. Yang, H.C.; Kao, J.H. Persistence of hepatitis B virus covalently closed circular DNA in hepatocytes: Molecular mechanisms and clinical significance. Emerg. Microbes Infect. 2014, 3, e64. [CrossRef] [PubMed]

99. Nassal, M. HBV cccDNA: Viral persistence reservoir and key obstacle for a cure of chronic hepatitis B. Gut 2015, 64, 1972-1984. [CrossRef] [PubMed]

100. Fung, J.; Lai, C.L.; Seto, W.K.; Yuen, M.F. Nucleoside/nucleotide analogs in the treatment of chronic hepatitis B. J. Antimicrob. Chemother. 2011, 66, 2715-2725. [CrossRef] [PubMed]

101. Huang, Y.W.; Chayama, K.; Tsuge, M.; Takahashi, S.; Hatakeyama, T.; Abe, H.; Hu, J.T.; Liu, C.J.; Lai, M.Y.; Chen, D.S.; et al. Differential effects of interferon and lamivudine on serum HBV RNA inhibition in patients with chronic hepatitis B. Antivir. Ther. 2010, 15, 177-184. [CrossRef] [PubMed]

102. Bottecchia, M.; Barcaiu, H.S.; Lewis-Ximenez, L.L.; da Silva EMouta Junior de Moraes, M.T. Monitoring the emergence of HBV resistance mutations by HBV-RNA pyrosequencing. Braz. J. Infect. Dis. 2016, 20, $216-217$. [CrossRef] [PubMed]

103. Wang, J.; Yu, Y.; Li, G.; Shen, C.; Meng, Z.; Zheng, J.; Jia, Y.; Chen, S.; Zhang, X.; Zhu, M.; et al. Relationship between serum HBV-RNA levels and intrahepatic viral as well as histologic activity markers in entecavir-treated patients. J. Hepatol. 2018, 68, 16-24. [CrossRef] [PubMed] 
104. Bonino, F.; Marcellin, P.; Lau, G.K.; Hadziyannis, S.; Jin, R.; Piratvisuth, T.; Germanidis, G.; Yurdaydin, C.; Diago, M.; Gurel, S.; et al. Predicting response to peginterferon alpha-2a, lamivudine and the two combined for HBeAg-negative chronic hepatitis B. Gut 2007, 56, 699-705. [CrossRef] [PubMed]

105. Manesis, E.K.; Hadziyannis, E.S.; Angelopoulou, O.P.; Hadziyannis, S.J. Prediction of treatment-related HBsAg loss in HBeAG-negative chronic hepatitis B: A clue from serum HBsAg levels. Antivir. Ther. 2007, 12, 73-82. [PubMed]

106. Wang, Y.C.; Yang, S.S.; Su, C.W.; Wang, Y.J.; Lee, K.C.; Huo, T.I.; .Lin, H.C.; Huang, Y.H. Predictors of response to pegylated interferon in chronic hepatitis B: A real-world hospital-based analysis. Sci. Rep. 2016, 6, 29605. [CrossRef] [PubMed]

107. Rijckborst, V.; Hansen, B.E.; Cakaloglu, Y.; Ferenci, P.; Tabak, F.; Akdogan, M.; Simon, K.; Akarca, U.S.; Flisiak, R.; Verhey, E.; et al. Early on-treatment prediction of response to peginterferon alfa-2a for HBeAg-negative chronic hepatitis B using HBsAg and HBV DNA levels. Hepatology 2010, 52, 454-461. [CrossRef] [PubMed]

108. Rijckborst, V.; Hansen, B.E.; Ferenci, P.; Brunetto, M.R.; Tabak, F.; Cakaloglu, Y.; Lanza, A.G.; Messina, V.; Iannacone, C.; Massetto, B. Validation of a stopping rule at week 12 using HBsAg and HBV DNA for HBeAg-negative patients treated with peginterferon alfa-2a. J. Hepatol. 2012, 56, 1006-1011. [CrossRef] [PubMed]

109. Boglione, L.; Cusato, J.; Cariti, G.; Di Perri, G.; D'Avolio, A. Role of HBsAg decline in patients with chronic hepatitis B HBeAg-negative and E genotype treated with pegylated-interferon. Antivir. Res. 2016, 136, 32-36. [CrossRef] [PubMed]

110. Goulis, I.; Karatapanis, S.; Akriviadis, E.; Deutsch, M.; Dalekos, G.N.; Raptopoulou-Gigi, M.; Mimidis, K.; Germanidis, G.; Drakoulis, C.; Triantos, C.; et al. On-treatment prediction of sustained response to peginterferon alfa-2a for HBeAg-negative chronic hepatitis B patients. Liver Int. 2015, 35, 1540-1548. [CrossRef] [PubMed]

111. Chevaliez, S.; Hezode, C.; Bahrami, S.; Grare, M.; Pawlotsky, J.M. Long-term hepatitis B surface antigen (HBsAg) kinetics during nucleoside/nucleotide analog therapy: Finite treatment duration unlikely. J. Hepatol. 2013, 58, 676-683. [CrossRef] [PubMed]

112. Zoutendijk, R.; Hansen, B.E.; van Vuuren, A.J.; Boucher, C.A.; Janssen, H.L. Serum HBsAg decline during long-term potent nucleos(t)ide analog therapy for chronic hepatitis B and prediction of HBsAg loss. J. Infect. Dis. 2011, 204, 415-418. [CrossRef] [PubMed]

113. Hosaka, T.; Suzuki, F.; Kobayashi, M.; Seko, Y.; Kawamura, Y.; Sezaki, H.; Akuta, N.; Suzuki, Y.; Saitoh, S.; Arase, Y.; et al. Clearance of hepatitis B surface antigen during long-term nucleot(s)ide analog treatment in chronic hepatitis B: Results from a nine-year longitudinal study. J. Gastroenterol. 2013, 48, 930-941. [CrossRef] [PubMed]

114. Seto, W.K.; Wong, D.K.; Fung, J.; Huang, F.Y.; Lai, C.L.; Yuen, M.F. Reduction of hepatitis B surface antigen levels and hepatitis B surface antigen seroclearance in chronic hepatitis B patients receiving 10 years of nucleoside analog therapy. Hepatology 2013, 58, 923-931. [CrossRef] [PubMed]

115. Chen, C.H.; Chiu, Y.C.; Lu, S.N.; Lee, C.M.; Wang, J.H.; Hu, T.H.; Hung, C.H. Serum hepatitis B surface antigen levels predict treatment response to nucleos(t)ide analogs. World J. Gastroenterol. 2014, 20, 7686-7695. [CrossRef] [PubMed]

116. Jaroszewicz, J.; Ho, H.; Markova, A.; Deterding, K.; Wursthorn, K.; Schulz, S.; Bock, C.T.; Tillmann, H.L.; Manns, M.P.; Wedemeyer, H.; et al. Hepatitis B surface antigen (HBsAg) decrease and serum interferon-inducible protein-10 levels as predictive markers for HBsAg loss during treatment with nucleoside/nucleotide analogs. Antivir. Ther. 2011, 16, 915-924. [CrossRef] [PubMed] 
117. Broquetas, T.; Garcia-Retortillo, M.; Hernandez, J.J.; Puigvehi, M.; Canete, N.; Coll, S.; Cabrero, B.; Gimenez, M.D.; Sola, R.; Carrion, J.A. Quantification of HBsAg to predict low levels and seroclearance in HBeAg-negative patients receiving nucleos(t)ide analogs. PLoS ONE 2017, 12, e0188303. [CrossRef] [PubMed]

118. Liaw, Y.F.; Kao, J.H.; Piratvisuth, T.; Chan, H.L.; Chien, R.N.; Liu, C.J.; Gane, E.; Locarnini, S.; Lim, S.G.; Han, K.H.; et al. Asian-Pacific consensus statement on the management of chronic hepatitis B: A 2012 update. Hepatol. Int. 2012, 6, 531-561. [CrossRef] [PubMed]

119. Liaw, Y.F.; Leung, N.; Kao, J.H.; Piratvisuth, T.; Gane, E.; Han, K.H.; Guan, R.; Lau, G.K.; Locarnini, S. Asian-Pacific consensus statement on the management of chronic hepatitis B: A 2008 update. Hepatol. Int. 2008, 2, 263-283. [CrossRef] [PubMed]

120. Hadziyannis, S.J.; Sevastianos, V.; Rapti, I.; Vassilopoulos, D.; Hadziyannis, E. Sustained responses and loss of HBsAg in HBeAg-negative patients with chronic hepatitis B who stop long-term treatment with adefovir. Gastroenterology 2012, 143, 629-636. [CrossRef] [PubMed]

121. Berg, T.; Simon, K.G.; Mauss, S.; Schott, E.; Heyne, R.; Klass, D.M.; Eisenbach, C.; Welzel, T.M.; Zachoval, R.; Felten, G.; et al. Long-term response after stopping tenofovir disoproxil fumarate in non-cirrhotic HBeAg-negative patients-FINITE study. J. Hepatol. 2017, 67, 918-924. [CrossRef] [PubMed]

122. Jeng, W.J.; Chen, Y.C.; Chien, R.N.; Sheen, I.S.; Liaw, Y.F. Incidence and predictors of hepatitis B surface antigen seroclearance after cessation of nucleos(t)ide analog therapy in hepatitis $\mathrm{B}$ e antigen-negative chronic hepatitis B. Hepatology 2018, 68, 425-434. [CrossRef] [PubMed]

123. Akbar, S.M.; Horiike, N.; Chen, S.; Michitaka, K.; Abe, M.; Hiasa, Y.; Matsuura, B.; Onji, M. Mechanism of restoration of immune responses of patients with chronic hepatitis B during lamivudine therapy: Increased antigen processing and presentation by dendritic cells. J. Viral Hepat. 2011, 18, 200-205. [CrossRef] [PubMed]

124. Ferrari, C. HBV and the immune response. Liver Int. 2015, 35 (Suppl. 1), 121-128. [CrossRef] [PubMed]

125. Chen, C.H.; Lu, S.N.; Hung, C.H.; Wang, J.H.; Hu, T.H.; Changchien, C.S.; Lee, C.M. The role of hepatitis B surface antigen quantification in predicting HBsAg loss and HBV relapse after discontinuation of lamivudine treatment. J. Hepatol. 2014, 61, 515-522. [CrossRef] [PubMed]

126. Liaw, Y.F.; Jeng, W.J.; Chang, M.L. HBsAg Kinetics in Retreatment Decision for Off-Therapy Hepatitis B Flare in HBeAg-Negative Patients. Gastroenterology 2018, 154, 2280-2281. [CrossRef] [PubMed]

127. Guardiola, A.A.; Gomez, R.R.; Romero, G.M.; Gomez Moreno, A.Z.; Garcia, V.A.; Sanchez, S.R.; Gomez, H.C.; Andres Esteban, E.M. Characteristics and course of chronic hepatitis B e antigen-negative infection. Gastroenterol. Hepatol. 2017, 40, 59-69. [CrossRef]

128. Thiele, M.; Gluud, L.L.; Fialla, A.D.; Dahl, E.K.; Krag, A. Large variations in risk of hepatocellular carcinoma and mortality in treatment naive hepatitis B patients: Systematic review with meta-analyses. PLoS ONE 2014, 9, e107177. [CrossRef] [PubMed]

129. Kim, J.H.; Sinn, D.H.; Kang, W.; Gwak, G.Y.; Paik, Y.H.; Choi, M.S.; Lee, J.H.; Koh, K.C.; Paik, S.W. Low-level viremia and the increased risk of hepatocellular carcinoma in patients receiving entecavir treatment. Hepatology 2017, 66, 335-343. [CrossRef] [PubMed]

130. Fu, S.; Li, N.; Zhou, P.C.; Huang, Y.; Zhou, R.R.; Fan, X.G. Detection of HBV DNA and antigens in HBsAg-positive patients with primary hepatocellular carcinoma. Clin. Res. Hepatol. Gastroenterol. 2017, 41, 415-423. [CrossRef] [PubMed]

131. Osawa, M.; Akuta, N.; Suzuki, F.; Fujiyama, S.; Kawamura, Y.; Sezaki, H.; Hosaka, T.; Kobayashi, M.; Kobayashi, M.; Saitoh, S.; et al. Prognosis and predictors of hepatocellular carcinoma in elderly patients infected with hepatitis B virus. J. Med. Virol. 2017, 89, 2144-2148. [CrossRef] [PubMed]

132. Lee, M.H.; Yang, H.I.; Liu, J.; Batrla-Utermann, R.; Jen, C.L.; Iloeje, U.H.; Lu, S.N.; You, S.L.; Wang, L.Y.; Chen, C.J. Prediction models of long-term cirrhosis and hepatocellular carcinoma risk in chronic hepatitis B patients: Risk scores integrating host and virus profiles. Hepatology 2013, 58, 546-554. [CrossRef] [PubMed]

133. Tseng, T.C.; Liu, C.J.; Yang, H.C.; Su, T.H.; Wang, C.C.; Chen, C.L.; Kuo, S.F.; Liu, C.H.; Chen, P.J.; Chen, D.S.; et al. High levels of hepatitis B surface antigen increase risk of hepatocellular carcinoma in patients with low HBV load. Gastroenterology 2012, 142, 1140-1149. [CrossRef] [PubMed]

134. Qu, L.S.; Liu, J.X.; Zhang, H.F.; Zhu, J.; Lu, C.H. Effect of serum hepatitis B surface antigen levels on predicting the clinical outcomes of chronic hepatitis B infection: A meta-analysis. Hepatol. Res 2015, 45, 1004-1013. [CrossRef] [PubMed] 
135. Tada, T.; Kumada, T.; Toyoda, H.; Kiriyama, S.; Tanikawa, M.; Hisanaga, Y.; Kanamori, A.; Kitabatake, S.; Yama, T.; Tanaka, J. HBcrAg predicts hepatocellular carcinoma development: An analysis using time-dependent receiver operating characteristics. J. Hepatol. 2016, 65, 48-56. [CrossRef] [PubMed]

136. Cheung, K.S.; Seto, W.K.; Wong, D.K.; Lai, C.L.; Yuen, M.F. Relationship between HBsAg, HBcrAg and hepatocellular carcinoma in patients with undetectable HBV DNA under nucleos(t)ide therapy. J. Viral Hepat. 2017, 24, 654-661. [CrossRef] [PubMed]

137. Soriano, V.; Barreiro, P.; Benitez, L.; Pena, J.M.; de Mendoza, C. New antivirals for the treatment of chronic hepatitis B. Expert Opin. Investig. Drugs 2017, 26, 843-851. [CrossRef] [PubMed]

138. Liang, T.J.; Block, T.M.; McMahon, B.J.; Ghany, M.G.; Urban, S.; Guo, J.T.; Locarnini, S.; Zoulim, F.; Chang, K.M.; Lok, A.S. Present and future therapies of hepatitis B: From discovery to cure. Hepatology 2015, 62, 1893-1908. [CrossRef] [PubMed]

(C) 2018 by the authors. Licensee MDPI, Basel, Switzerland. This article is an open access article distributed under the terms and conditions of the Creative Commons Attribution (CC BY) license (http://creativecommons.org/licenses/by/4.0/). 